\title{
Efforts to Increase Science Learning Outcomes by Increasing Interaction Between Students in Learning
}

\author{
Astri Widyasari ${ }^{*}$, Pratiwi Pujiastuti, Nada Savitri Nawangsari, Albi Anggito \\ Faculty of Education, Universitas Negeri Yogyakarta, Indonesia \\ "Corresponding author. Email: astriwidyasari.2020@student.uny.ac.id
}

\begin{abstract}
Students experiencing difficulties in learning sometimes feel embarrassed to ask the teacher. They feel more comfortable asking their peers instead of their teachers. Therefore, there is a need to increase interaction and exchange between students. The researcher conducted a Classroom Action Study to determine whether student interaction can improve learning outcomes. This study aims to improve learning outcomes through increased student interaction using cooperative learning models. The subjects in this study were 37 grade IV elementary school students. Data was collected by giving written tests to students. Data analyzed by quantitative descriptive. Based on research, the average learning outcomes increase from 68.05 to 77.29 , which means that interaction between students can improve their learning outcomes.
\end{abstract}

Keywords: learning outcomes, science learning, students' interaction

\section{INTRODUCTION}

The students' interaction can broaden the students' perspective to solve problems they encounter. Interaction plays an essential role in the learning process. Interaction between students should be constructed so that the knowledge provided can be received better [1]. Science learning is a process of interaction and cooperation between students and educators, learning resources, learning media, and a learning environment to achieve the competence of science that has been determined.

The achievement of outcomes learning proves that the student has well-developed cognitive ability. Students can become more optimistic when equipped with a set of cognitive skills. We can know that the ability cognitive is an activity and thought process, which consists of the ability of individuals to connect, assess, and consider an event or events. Cognitive development students are associated with the brain's capacity and related closely with the level of intelligence [2].

The cognitive functions are to think, remember, analyze, study, and mental activity [3]. The cognitive processes associated with the level of intelligence that marks a person with various interests are primarily addressed to the ideas of learning by learners. For example, the reaction and thought of students "A" to the exam is a negative emotion, then the reaction that will "A" give is crying and not studying for the next exam. Conversely, when a student's "A" reaction is a positive and optimistic emotion with positive changes in their thoughts and feelings, they may change their behaviors and start planning to study for the next exam [4].

There are a variety of learning models that teachers can use to help increase learning outcomes [5]. One of which is teacher-centered learning. This learning model is one direction where students force to swallow all sorts of information given by the teacher. It makes students more confused [6]. They received one of the kinds of data, which they should produce various kinds of information to answer the question. From this, students do not have much perspective for comparing. What is the material that they caught, right? Is it enough? Whether they can use it to solve the problems that they encounter?

On the other hand, students feel ashamed to ask the teacher about the material they did not understand. This 
behavior will worsen their ability to understand and the ability to solve problems that they encounter. The students' inability to develop the knowledge and skills, making learning outcomes of students decreased, so did the value of the affection and psychomotor students [7].

They were learning models with authentic, challenging, and meaningful students. Potential students can develop following the expectations of national education goals [8]. The learning model is key to the success of a learning activity because as good as any substance of the material and media used by the teacher. Still, the meaning will not be upon the students without the packaging and delivery of an exemplary process.

Model Team Assisted an Individualization is a learning group that puts students in small groups consisting of two or more students who are heterogeneous helps each other in learning the material [9]. This model emphasizes the mutual dependence of the positive among the child, the responsibilities of each, meeting face-to-face, intensive communication, and evaluating the group process to manage the class to be more efficacious [10].

Based on the results of observations and interviews with fifth-grade teachers in Tlogoadi Primary School from July to August 2019, declared science subjects are a lesson that is difficult for students to understand. The results of learning science have not reached the minimum score. The lack of student interaction skills results in a lack of ability to discuss and the courage to ask the teacher.

The advantage of using this method is that the students' habits in solving the problem generally ask their colleagues than ask the teacher. Difficulty understanding the material that the student's experience can be translated together with the working group and the teacher's guidance. With Team Assisted Individualization, it is expected that students with difficulty understanding the concept of material or are ashamed to ask the lecturer can be overcome by asking a friend who is capable in his group [11].

Through Team Assisted Individualization, students can communicate more intensively with their group peers to exchange understanding about the material they are studying together. Interaction between students can reduce the dominance of teachers in classroom learning and focus more on learning to students.

Based on the argument above, allowing students to interact with each other can increase the learning outcomes. The interaction performed by the student either during learning or outside the teaching will give them a new brand perspective that can enrich the students' understanding. The low learning outcomes can be overcome by increasing awareness and optimizing various learning resources, including the interaction and exchanging views with the other students.

Providing an opportunity for students from different backgrounds to work and depend on each other to perform tasks together and learn to respect one another can improve the student's understanding [12]. Providing opportunities for students to work together cooperatively can influence learning outcomes[13]. Interaction between students can motivate activities learning to make it easier for students to understand, understand the material can give a more meaningful learning experience [14].

This study focuses on how Team Assisted Individualization can improve student interaction and student learning outcomes.

\section{RESEARCH METHODS}

The type of research is classroom action research, which is essentially research conducted at the time of teaching in the classroom and aims to improve the quality of teaching and learning process. This study used the design cycle model from Kemmis \& Taggart (1988), consisting of three stages, planning, implementation, class and observation, and reflection [15].

Researchers collaborate with the teacher to prepare the teaching necessary to implement the action and observation at the planning. The steps are applied in the stage of planning is; 1) observe the characteristics of the students; 2) collaborate with classroom teachers regarding the determination of the material that will be used in the research; 3) preparing the research instrument that consists of guidelines for the assessment of the results of pre-cycle, the guidelines increase student interaction and observation sheets feasibility study.

On the implementation, the teacher following the learning implementation plan has been prepared by the researchers and adjusted for changes in conditions of the class. Observations were made simultaneously with the implementation of the action, during the learning process, collaborating in the performance. The stage of reflection is intended as an attempt to assess the cycle implemented. The reflection results are used to define the next steps to produce improvement in the following processes.

The techniques used to collect data in this research are tests and observation. The learning test results contain 20 item multiple-choice questions covering aspects of cognitive $\mathrm{C} 1, \mathrm{C} 2, \mathrm{C} 3$, and $\mathrm{C} 4$ associated with learning material.

The research data are collected like test scores and observation scores and then analyzed by the 
researcher-research using quantitative and qualitative descriptive analysis. The study is used to process the data the test results. The researcher used a question sheet. The quantitative data obtained were then analyzed by calculating the actual total score of the students using the equation, where $\mathrm{N}=$ student grade, $\Sigma X=$ total score, and $\mathrm{n}=$ number of rated items. This research is considered successful if the class average is $>72$.

$$
N=\frac{\Sigma X}{n}
$$

\section{FINDINGS AND DISCUSSION}

Class action research aims to improve learning outcomes by increasing student interaction by applying the cooperative learning model type Team Assisted Individualization. The study was conducted in Tlogoadi Primary School is located at Kebon Agung Street No. 354, Area Sawah, Tlogoadi, Mlati, Sleman Districts, Daerah Istimewa Yogyakarta. Subject research students of fifth-grade with the number of students 37, consists of 13 female students and 24 male students. The precycle activities include observation of the state of the class, interviews with teachers discussing lesson plans, learning models used, learning media, and the technical assessment will be implemented.

This research was conducted in two cycles. Each cycle consists of two meetings with 3 to 4 hours of lessons with the scope of simple material. The action in the process I discuss the heat transfer. Cycle II discusses heat transfer and its benefits in daily life. The data in this research was obtained through tests and observation

\subsection{Pre-Cycle}

On the activities of the pre-cycle visible presence of interaction between teachers and students in two directions, or the interaction of the students. Through learning with model thus, the results of student learning can be seen in table 1 .

Table 1. Results of Learning Science

\begin{tabular}{|c|c|}
\hline Aspects & Results \\
\hline Average & 68.05 \\
\hline Standard Deviation & 6.36 \\
\hline Highest value & 82 \\
\hline Lowest value & 56 \\
\hline $\begin{array}{l}\text { Percentage of students due } \\
\text { to }\end{array}$ & $35.13 \%$ \\
\hline $\begin{array}{l}\text { Percentage of students who } \\
\text { did not complete }\end{array}$ & $64.86 \%$ \\
\hline
\end{tabular}

Learning outcomes students have an average value of 68.05 on the pre-cycle activities. The percentage of students completed or the student's grades $\geq 72$ achieve to $35.13 \%$ with the number of students as many as 13 students, students who did not complete with the percentage of $64.86 \%$ or as many as 24 students. The table shows that the condition of the overall value of student learning outcomes is still low, so action needs to be taken to increase the value. In charge of science, there is the material that is not enough to memorize, and the science needs to be understood that the memory of the students of the material can last a long time.

Students who have difficulty exchanging ideas and interacting can hinder the learning process. The lack of opportunities to work in groups is one of the reasons students are less able to exchange ideas, even though group work activities will make it easier for students to understand the material and solve the problems they receive [16]. With the above considerations, the researcher and the teacher decided to start cycle 1.

\subsection{Cycle I}

There is an interaction among others; there are students who choose a friend of one group, even so, the students still wanted to work with friends in completing group assignments. Students can discuss better. In addition, they also encourage other students who have yet to give an opinion so brave to share or express their belief in completing the task group.

Team Assisted Individualization's learning model runs with less than the maximum in the first cycle and requires repair. Through the activities of learning by the learning model Team Assisted Individualization done by the teacher, the science learning outcomes of students have increased. Here is presented table 2 of student learning outcomes in cycle I.

Table 2. Results of Learning Science

\begin{tabular}{|l|l|}
\hline Aspects & Results \\
\hline Average & 70.81 \\
\hline Standard Deviation & 12.21 \\
\hline Highest value & 95 \\
\hline Lowest value & 55 \\
\hline $\begin{array}{l}\text { Percentage of students due } \\
\text { to }\end{array}$ & $35.13 \%$ \\
\hline $\begin{array}{l}\text { Percentage of students } \\
\text { who did not complete }\end{array}$ & $64.86 \%$ \\
\hline Source: Results of data processing, 2021
\end{tabular}

Based on table 2, the average learning outcomes of science students of fifth-grade Tlogoadi Primary School are 70.81 . Students with an average above 72 as much as $35.13 \%$. 
The results of the research cycle after the teacher used a model of cooperative learning type Team Assisted Individualization in learning shows that the average value of science learning outcomes of students increased to 70.81 after the students worked together in a group. A student who wants to learn in a group can improve the ability to ask and argue with other students to exchange ideas and knowledge with other group members [17]. The model can help the students better understand the material given by the teacher because the students are involved in the learning process.

On implementing the action cycle, I experienced several shortcomings, so I need to repair the implementation of cycle II. Improvements made include the students affirmed that the group's work is the responsibility of all group members, so all group members must complete the task group. Through these improvements, it is expected an improvement in the result of action cycle II

\subsection{Cycle II}

The second cycle executed as many as two meetings. Overall the teachers have carried out all the syntax of the learning model Team Assisted Individualization. Even so, some stages are less than optimal in their implementation. Model Team Assisted Individualization implemented $100 \%$. In the second cycle, the teacher has to repair the steps of a less than optimal on the actions of the process, such as the delivery of learning objectives, presentation of information related to the technical work, exams, and giving value, so that the activities of learning by using learning model Team Assisted Individualization has been running better.

In the observation of the interaction of the students in the second cycle are increased interaction of students. The upgrade includes student one class member to be a friend of one of the others. Students can discuss better, give each other opinions, accept opinions without coercion from the teacher. Through the activities of learning by using the learning model Team Assisted Individualization that is done by the teacher, the science learning outcomes of students have increased. The test student's science learning outcomes presented in cycle II are in table 3 .

Table 3. Results of Learning Science

\begin{tabular}{|l|l|}
\hline Aspects & Results \\
\hline Average & 77.29 \\
\hline Standard Deviation & 9.68 \\
\hline Highest value & 95 \\
\hline Lowest value & 60 \\
\hline Percentage of students due & $72.97 \%$ \\
\hline
\end{tabular}

\begin{tabular}{|l|l|}
\hline to & \\
\hline $\begin{array}{l}\text { Percentage of students who } \\
\text { did not complete }\end{array}$ & $27.02 \%$ \\
\hline Source: Results of data processing, 2021 &
\end{tabular}

Based on the data in table 3, the learning model Team Assisted Individualization in learning activities can improve science learning outcomes of fifth-grade Tlogoadi Primary School after the second cycle. Students' average value is 77.29. Students with an average above 72 as much as $72.97 \%$.

The comparison of improving learning outcomes starting from the pre-cycle, cycle I, and cycle II is explained in Table 4. Based on the data in table 4, explain that the learning model Team Assisted Individualization in learning activities can improve science learning outcomes of students of fifth-grade Tlogoadi Primary School. Before being subjected to the action of the second cycle, the average value of learning outcomes science is 68.05 , and after the second cycle, the average value of students is 77.29.

Table 4. Results of Learning Science Comparison

\begin{tabular}{|l|l|l|l|}
\hline Aspects & $\begin{array}{l}\text { Pre } \\
\text { Cycle }\end{array}$ & Cycle I & Cycle II \\
\hline Average & 68.05 & 70.81 & 77.29 \\
\hline $\begin{array}{l}\text { Std. Deviation } \\
\text { Percentage of } \\
\text { students due } \\
\text { to }\end{array}$ & $35.13 \%$ & 12.21 & 9.68 \\
\hline $\begin{array}{l}\text { Percentage of } \\
\text { students who } \\
\text { did not } \\
\text { complete }\end{array}$ & $64.86 \%$ & $64.86 \%$ & $72.97 \%$ \\
\hline
\end{tabular}

The students can provide input on the work of a friend of one of the others, resulting in checking each other. Students exchange ideas and knowledge during the learning group. Working in a group can encourage students to encourage each other and help each other to solve the problem given by the teacher. A student with skill mastery communication will be easy to share various things concerning the closeness of the personal learning materials, both orally and in writing to achieve success in understanding the material [19].

The discussion shows that applying the cooperative learning model type Team Assisted Individualization in learning thematic charged science can improve science learning outcomes and attitude of working together with the students of fifth-grade Tlogoadi Primary School. 
Every material and task of learning have their characters. Without communication between teachers and students, they cannot be inherently interconnected and readily accepted. A teacher should allow students to explore their interests without any pressure. Meanwhile, teachers can help students understand the value of learning materials or use them personally to perform the learning activities, which gradually guides students to realize the internalization of the spirit of learning [20].

Each sequence of the learning experience consists of the contents and the activity of the learning environment, learning process, and learning outcomes [21]. In addition to increasing student interaction, the interaction between teachers and students is also an essential key in education. The exchange has a role in the success of learning in the classroom. Good interactions will produce increasing student scores.

To improve affiliate relationships between teachers and students, the teacher can improve student interaction. Compared with the exchange that focuses on the learning materials, the interaction that focuses on the meaning of learning refers to the focus and the understanding of meaning in the teaching more readily accepted by students. Teachers can use the inductive way to teach the material by providing more examples to illustrate the factual circumstances around the students and make the students depict the creativity to the problem following the context of the material. Teachers can correct students' mistakes in conversation communicative interaction [22].

Teachers tasked to create an environment of the interaction of a class that does not bring a sense of distress and gives the freedom to the students can be argued. The students' initiation of questions improves the quality of interaction between teachers and students, enhancing the quality of learning. Quality of learning will create resilient children. When children are resilient, they are self-confident, inquisitive, adapt to the new situation, and more skilled to expand and reach out to the world [23].

\section{Conclusion}

Increasing student interaction can improve student learning outcomes. In the initial conditions, the average value of science learning outcomes in class $\mathrm{V}$ was 68.05. Through increased interaction, students rose to 70.81 in the first cycle. In the second cycle, the average student learning outcomes increased to 77.29. Increasing student interaction using the Team Assisted Individualization type of cooperative learning model can improve student learning outcomes. Team Assisted Individualization can enhance the learning process in the classroom because there are opportunities for students to interact with each other and allow students to open new windows to increase their ability to see and find solutions to the problems they receive. The classroom teacher needs to understand the low interaction between students that affects student learning outcomes to overcome it.

\section{ACKNOWLEDGMENTS}

This research was supported by Universitas Negeri Yogyakarta. The authors would like to thank Universitas Negeri Yogyakarta, who has provided suggestions and corrections that are very helpful for this research

\section{REFERENCES}

[1] A. Gultom and Suhartini, Student Interaction, Teacher Competence, and Technology in Online Learning: Does it Create a Meaningful Learning?, Proc. 6th Int. Semin. Sci. Educ. (ISSE 2020), vol. 541, no. Issue 2020, pp. 169-180, 2021, DOI: 10.2991/assert.k.210326.024.

[2] P. Peng and R. A. Kievit, The Development of Academic Achievement and Cognitive Abilities: A Bidirectional Perspective, Child Dev. Perspect., vol. 14, no. 1, pp. 15-20, 2020, DOI: 10.1111/cdep.12352.

[3] T. J. Shuell, cognitive conceptions of learning, Rev. Educ. Res., vol. 56, no. 4, pp. 411-436, 1986, DOI: $10.3102 / 00346543056004411$.

[4] G. R. Thew, Online cognitive behavioral therapy: an e-mental health approach to depression and anxiety., vol. 47, no. 5. 2019.

[5] M. K. Nasution, Penggunaan metode pembelajaran dalam peningkatan hasil belajar siswa, Stud. Didakt. J. Ilm. Bid. Pendidik., vol. 11, no. 1, pp. 916, 2017.

[6] J. M. Lodge, G. Kennedy, L. Lockyer, A. Arguel, and M. Pachman, Understanding Difficulties and Resulting Confusion in Learning: An Integrative Review, Front. Educ., vol. 3, no. June, pp. 1-10, 2018, DOI: 10.3389/feduc.2018.00049.

[7] W. Alannasir, Characteristic-Based Development Stundes Aspect, Int. J. Asian Educ., vol. 1, no. 1, pp. 29-36, 2020.

[8] D. W. Aisyah, M. Gipayana, and E. T. Djatmika, Mengembangkan kebermaknaan belajar dengan rancangan pembelajaran tematik bercirikan quantum teaching, Semin. Nas. Mhs. Kerjasama Direktorak Jendral Guru dan Tenaga Kependidikan Kemdikbud, pp. 1-7, 2016.

[9] Sulaiman, The Effectiveness of team assisted individualization in teaching vocabulary viewed from students ' motivation, J. Pendidik. 
Bhs., vol. 4, no. 2, pp. 264-280, 2015.

[10] G. M. Tinungki, The role of coo perative learning type team assisted individualization to improve the students' mathematics communication ability in the subject of probability theory,Proc. of fifth Conf. Psychol. Math. Educ., vol. 6, no. 32, pp. 2731, 2015, [Online]. Available: https://eric.ed.gov/?id=EJ1083611.

[11] L. Rudi, Application of teaching model of team assisted individualization [TAI] in basic chemistry courses in students of forestry and science of environmental, Universitas Halu Oleo, vol. 5, no. 11. 2017.

[12] Trianto, Model Pembelajaran Terpadu Konsep, Strategi Dan Implementasinya Dalam Kurikulum Tingkat Satuan Pendidikan (KTSP). Jakarta: Bumi Aksara, 2011.

[13] R. T. Johnson and D. W. Johnson, student-student Interaction: Ignored but Powerful, J. Teach. Educ., vol. 36, no. 4, pp. 22-26, 1985, DOI: $10.1177 / 002248718503600406$.

[14] A. L. Sari and Dkk, pengaruh model pembelajaran interaksi sosial terhadap hasil belajar ips siswa kelas iv di sd gugus 1 kecamatan Tabanan, J. Univ. Pendidik. Ganesha, vol. 1, no. 1, pp. 1-10, 2013.

[15] B. Anne, Doing Action Research in Language Teaching: A Guide for Practitioners. 2010.

[16] I. Mallipa, The implementation of group works on english education students at the university of Papua: the perceptions and problems, Linguist. English Educ. Art J., vol. 1, no. 2, pp. 193-204, 2018, DOI: 10.31539/leea.v1i2.182.

[17] M. Laal and M. Laal, Collaborative learning: What is it?, Procedia - Soc. Behav. Sci., vol. 31, no. 2011, pp. 491-495, 2012, DOI: 10.1016/j.sbspro.2011.12.092.

[18] A. A. I. Evayanti1, I. K. N. Wiyasa, and I. G. Meter, Model pembelajaran kooperatif tipe team asissted individualy (TAI) berbasis concept mapping berpengaruh terhadap hasil belajar IPS siswa kelas V SD Gugus III Gianyar, Mimb. PGSD Univ. Pendidik, Ganesha, vol. 2, no. 1, 2014, [Online]. Available: https://ejournal.undiksha.ac.id/index.php/JJPGSD/ article/view/4386/3388.

[19] S. Maryanti, Zikra, and Nurfarhanah, Hubungan antara keterampilan komunikasi dengan aktivitas belajar siswa, Konselor, vol. 1, no. 2, pp. 1-9, 2012, DOI: 10.24036/0201212700-0-00.

[20] M. L. Wehmeyer and K. A. Shogren, The development of self-determination during adolescence. 2017.

[21] K. Solheim, S. K. Ertesvåg, and G. Dalhaug Berg, How teachers can improve their classroom interaction with students: New findings from teachers themselves, J. Educ. Chang., vol. 19, no. 4, pp. 511-538, 2018, DOI: 10.1007/s10833-0189333-4.

[22] L. Liu, Strategies to improve teacher-student Interactions in Senior Schools in Western China, US-China Foreign Lang., vol. 15, no. 2, pp. 76-80, 2017, DOI: 10.17265/1539-8080/2017.02.002.

[23] M. Pettoello-Mantovani et al., Fostering resilience in children: the essential role of healthcare professionals and families, J. Pediatr., vol. 205, pp. 298-299.e1, 2019, DOI: 10.1016/j.jpeds.2018.10.069. 